\title{
Intergenerational Social Mobility and Popular Explanations of Poverty: A Comparative Perspective
}

\author{
Alexi Gugushvili ${ }^{1,2}$ (D) \\ Published online: 23 November 2016 \\ (C) The Author(s) 2016. This article is published with open access at Springerlink.com
}

\begin{abstract}
This article explores the consequences of intergenerational social mobility on perceptions of popular explanations of poverty. It is hypothesised that those who experience improvements in socio-economic status through social mobility are more likely to blame poverty on individual characteristics such as laziness and lack of willpower and are less likely to attribute failure to injustice in society, and on the macro-level, the effect of social mobility on perceptions of popular explanations of poverty is moderated by contextual environment. The described hypotheses are tested by using multinomial and multilevel logistic regressions and two complementary datasets-European Values Studies and the Life in Transition Survey. The derived findings suggest that social mobility is indeed associated with perceptions of individual blame and social blame of why some people are in need. However, these effects are manifested primarily among subjectively mobile individuals and are also conditioned by the legacy of socialism and the level of economic development of countries where individuals reside.
\end{abstract}

Keywords Intergenerational social mobility - Social justice - Subjective mobility · Poverty explanations · Fairness · Multilevel analysis

\section{Introduction}

In achievement-oriented societies, attained socio-economic status results from individuals' abilities and efforts to improve their own lives. If in these societies, life chances depend on ascribed factors rather than achieved ones, they are inherently

Alexi Gugushvili

alexi.gugushvili@spi.ox.ac.uk

1 Department of Social Policy and Intervention and Nuffield College, University of Oxford, Barnett House, 32 Wellington Square, Oxford OX1 2ER, UK

2 Department of Sociology, University of Cambridge, Cambridge, UK 
unjust (Parsons \& Shils, 1951). Low rate of intergenerational social mobility, which refers to restricted movement upward or downward in the prevailing stratification hierarchy, is considered as representing one of the most fundamental forms of ascriptive inequality (see Blau \& Duncan, 1967; Breen, 2004; Erikson \& Goldthorpe, 1992). Many existing studies on intergenerational social mobility are motivated by the normative considerations of strong intergenerational links in socioeconomic status (Marshall \& Swift, 1996; Marshall, Swift, \& Roberts, 1997; Swift, 2000), but social mobility is not an end in itself and should be "informed as much by an explanatory as a normative interest" (Swift, 2004, p. 1). One of the ways of understanding social mobility for individuals' lives is to analyse how the attitudes of people with different mobility experiences vary. If we have to select among various potential sets of attitudes related to social mobility, views on the determinants of life chances are the obvious choice. The major question of this article is whether or not individuals' social mobility experience correlates with their perceptions of popular explanations of poverty. The importance of public perceptions of poverty for welfare state policies is widely recognised, but much more needs to be done for understanding the multifaceted nature of public attitudes towards the poor (Kallio \& Niemelä, 2014).

It is generally acknowledged, at least on theoretical level, that intergenerational social mobility is an important explanation of attitudes towards inequalities (JaimeCastillo \& Mareques-Perales, 2014; Wegener \& Liebig, 1995). According to Kluegel and Smith (1986), people who experience improvements in living standards through social mobility are more likely to attribute their success to their own effort and abilities. Although the exact reason for this tendency is unknown, it is believed to be driven by various psychological mechanisms (Burger, 1981; Crocker \& Park, 2004; Ross, 1977). To my knowledge, there are hardly any studies that empirically investigate the links between intergenerational social mobility and perceptions of popular explanations of poverty in large comparative perspective. Furthermore, comparative research addressing implications of social mobility on individuals' attitudes and behaviours rarely includes a large number of post-socialist societies. This article not only contributes to the literature on the consequences of social mobility and perceptions of popular explanations of poverty, but also inquiries whether the strength of this link depends on countries' contextual environment- the legacy of socialism and economic development.

In addition, I also consider the effects of both objective intergenerational occupational mobility and subjective self-reported mobility experience on attitudes towards poverty determinants. The latter distinction is an important contribution to the literature as the existing studies usually analyse independently either objective or subjective mobility experiences. Individuals' attitudes might be affected by mobility only if they are conscious of their upward or downward mobility experience. To address the research question of this article, I employ two complementary large-scale datasets-European Values Studies (EVS) and the Life in Transition Survey (LITS). I start with the short review of the theoretical framework and corresponding micro- and macro-level hypotheses on the role of mobility in attitudes towards the attributes of poverty. Particular attention is paid to the utilised variables in the research design overview. The results section presents 
the empirical findings based on the conducted multivariate and multilevel analysis. The final section summarises the results, discusses the problems of causality, and briefly outlines the implications of findings for the policymaking realm.

\section{Theoretical Framework}

Scholarly interest in popular poverty attributions originates after the 1960s in the USA, coinciding with the "War on Poverty" agenda initiated by President Lyndon B. Johnson's administration. The earliest studies using formal factor analysis distinguished between explanations concerned with socio-economic influences, with personal responsibility, and with personal misfortune (Feagin, 1972; Feather, 1974). According to these findings, individualistic explanations put responsibility for destitution on the poor themselves; structural explanations blame the external and socio-economic forces for deprivation; fatalistic ideas perceive poverty as the result of factors beyond individuals' and social control. While this approach simplifies the complexity of popular attributions of poverty (e.g. Morçöl, 1997; Smith \& Stone, 1989), it still provides a comparatively validated classification of popular explanations about the causes of poverty (Lepianka, Van Oorschot, \& Gelissen, 2009). Researchers usually find that individuals' gender, education, labour market status, social class, income, subjective experience of disadvantage, and personal ideological convictions all play a role in attitudes towards poverty determinants (Alston \& Dean, 1972; Bucca, 2016; Feather, 1974; Kallio \& Niemelä, 2014; Kreidl, 2000; Niemela, 2008; Stephenson, 2000; Wegener, 2000; Zucker \& Weiner, 1993).

\section{Self-Serving Bias in Causal Attribution, Objective Versus Subjective Social Mobility}

It is known that rational self-interest is one of the micro-level mechanisms that affect attitudes towards life chances and inequality (Linos \& West, 2003), but an important social-psychological concept that may best explain why socially mobile individuals differ in their understanding of the causes of poverty is the self-serving bias in causal attribution (see Schmidt, 2011). Causal attribution refers to "the process by which social perceivers arrive at causal explanations for their own, as well as others' behaviours" (Semin \& Zwier, 1997, p. 55). The self-serving bias implies that people are more likely to attribute failure to factors that are beyond their control and more likely to explain successes by pointing to their own merits, abilities, and effort. According to Miller and Ross (1975, p. 23), the self-serving bias is related to individuals' need to have control over their environment: "the attribution to self of success and the attribution to external factors of failure provides for the continuation of control attempts". The existing evidence clearly indicates the pervasiveness of the self-serving attribution bias in various countries and contexts and also suggests significant heterogeneity across societal groups (Mezulis, Abramson, Hyde, \& Hankin, 2004). 
It is known that some individuals in a society believe that predetermined circumstances are more decisive than one's own effort in shaping life achievements, but others are convinced that individual effort rather than ascribed circumstances is the key to seizing life chances. The intra-family theoretical model, proposed by Piketty (1995), assumes that these perceptions are largely affected by lifelong experiences. Depending on their origin, individuals start with an initial set of attitudes, but over the years these preferences are amended based on their experience of intergenerational mobility and an associated self-serving perception of the role that ascribed and attained factors play in determining success or failure. What this means is that individuals who experience upward social mobility will be more likely than non-mobile individuals to make internal attributions such as laziness to describe individuals' failure. We should expect downwardly mobile individuals to make external attributions and to be more in favour of the notation that individuals are not accountable for their own poverty. Furthermore, a qualitative study of individuals in France suggests that upwardly mobile people predominantly emphasise personal merit in their success (Duru-Bellat \& Kieffer, 2008).

Since my empirical analysis deals with the links between social mobility and attitudes, a distinction between objective upgrading in occupational status and subjective perception of the intergenerational social mobility experience is of primary importance. If the former can be measured by the association between social background and occupational attainment, the latter can be investigated though individuals' qualitative assessment of their own social mobility experience (van den Berg, 2011). Relationships between subjective and objective mobility are generally, but not always, positive. The analysis of data for 30 nations which asked respondents to compare their own occupational status with the status of their father's job indicated that objective intergenerational mobility had an important effect on subjective mobility perceptions (Kelley \& Kelley, 2009). On the other hand, according to Segura (1989), some immigrants in the USA define their mobility experience as upward, although it would qualify as downward according to objective definitions of social mobility. Empirical evidence suggests that subjective mobility is correlated with a broader set of socio-demographic factors (Evans \& Kelley, 2004). The first hypothesis of this paper that refers to both objective and subjective social mobility takes the following form:

H1: (1a) Intergenerational upward social mobility positively associates with attitudes that individuals are responsible for their own failure; (1b) intergenerational upward social mobility negatively associates with attitudes that injustice in society is responsible for people being in need.

\section{Socialist Legacy and Economic Development}

Existing research suggests that significant macro-level factors that affect individuals' perceptions of popular explanations of poverty are welfare state institutions, social expenditure, economic growth, a country's religious traditions, and level of poverty (Kallio \& Niemelä, 2014; Kluegel, Mason, \& Wegener, 1995; Lepianka, 
Gelissen, \& van Oorschot, 2010). In this subsection, I review two macro-level mechanisms which could moderate the effect of social mobility on individuals' perceptions of poverty attributes. The legacy of socialism in Central and Eastern Europe has been shown to exert a long-lasting effect on post-socialist economic and political attitudes (Pop-Eleches \& Tucker, 2014). Perceptions of popular explanations of poverty can stem from the idiosyncratic national characteristics and distinctive historical legacies of these countries. One of the main findings of this stream of the literature is that post-socialist societies overall have a higher tendency to favour individual explanations of poverty (Kallio \& Niemelä, 2014). Fatalistic explanations of poverty are also less common in this region (Kreidl, 2000; Lepianka et al., 2010; Oorschot \& Halman, 2000).

In addition to individual-level mobility experience, intergenerationally mobile citizens of more fluid societies are more likely to have individualistic worldviews on failure and success in life (Bucca, 2016). In the countries of the socialist bloc, more ambitious de-stratification policies led to higher mobility rates which to this day shape their intergenerational social mobility regimes (Gugushvili, 2014, 2015a; Parkin, 1973). Indeed, one of the main conclusions of five decades of social stratification and mobility research is that the fundamental determinants of life chances are resistant to change (Hout \& DiPrete, 2006). Socialist institutions and individuals embedded in them are likely to have remained the source of postsocialist reproduction and stratification through structural and economic inertia (Rona-Tas \& Guseva, 2001). The latter is particularly important as the available studies also suggest that a feedback mechanism exists between public attitudes in a country and its economic and political institutions (Alesina \& Glaeser, 2004; Breznau, 2016; Linos \& West, 2003).

In many post-socialist societies, the prevailing corrupt practices of resource distribution have both disrupted socialist egalitarian policies and prompted the emergence of crony capitalism (Smith, 2010). The latter could mean that the limited role of the state in addressing social hardship facilitates the prevalence of individualistic explanations among socially mobile individuals on why some people in their society are in need (Bucca, 2016). One could also argue in the opposite direction that individuals are likely to attribute poverty to the state in post-socialist societies because the state does so little to address social hardships. However, the reluctance of the elites, political leaders and opinion makers to support the new poor by equally sharing the costs of the transition has been extensively demonstrated (see Atal, 1999; Fodor, Wnuk-Lipinski, \& Yershova, 1995; Szelényi \& Szelényi, 1995). It is also worth noting that the values underpinning policies that address poverty such as equality or solidarity have become more de-legitimated in post-socialist countries than they are in the developed democracies of Western Europe (Ferge, 1997).

A distinction between post-socialist countries and Western European democracies is also important inasmuch as Kreidl (2000), in this journal, argued that in the first years of post-socialist transition, the effect of upward social mobility in Eastern European societies, among other explanations, was much less salient in explaining poverty simply because upward social mobility was the exception. However, the latest available comparative evidence suggests that no drastic changes have taken 
place in terms of social fluidity since the collapse of the Berlin Wall and the levels of upward intergenerational mobility remained quite high (Gugushvili, 2014; Veraschagina, 2012). Therefore, Kreidl's conclusion that social mobility in postsocialist countries cannot affect the legitimisation of poverty as in the Western welfare democracies needs to be re-examined. The following is the second hypothesis of this article:

H2: The effect of intergenerational social mobility on attitudes towards the determinants of poverty is stronger in post-socialist societies than it is in other European societies.

The second macro-level hypothesis implies that perceptions of popular explanations of poverty among socially mobile individuals are affected by the economic performance of their countries (Giuliano \& Spilimbergo, 2013). More specifically, I test the moderating effect of the macro-contextual variable-economic development. A favourable macroeconomic context can facilitate individualistic beliefs not only among socially mobile groups but also among all individuals because economic growth is likely to be perceived as some sort of collective upward mobility. Furthermore, upwardly mobile individuals in economically advanced environments might have an extra reason to oppose structural explanations and support individualistic explanations of poverty because economic development, on average, provides greater opportunities to succeed in life (Weber, 1978). The links between economic development and individualism, and therefore individualistic explanations of poverty, preoccupied some of the most influential thinkers in social science history. Examples include Smith's (1817) invisible hand of an individualistic society which leads to greater economic prosperity for all, and Max Weber's description of "the ability to free oneself from the common tradition, a sort of liberal enlightenment, [which] seems likely to be the most suitable basis for [such] a business man's success" (Weber, 2005 [1930]:32).

Recently, the idea of economic development promoting individualism became widespread in popular and academic thinking (Ball, 2001). By comparing the cashbased blood supply system in the USA with the UK's voluntary system, Titmuss (1970) famously illustrated how the market exchange weakens cooperative norms of behaviour and promotes rational individualism. Similarly, Inglehart (1997) went beyond the question, "is economic growth due to cultural factors or does economic growth somehow give rise to a culture that is facilitative to growth?" and argued that economic prosperity and individualised worldviews are interconnected and provide an explanation of why some societies are rich and others are poor. A recent methodologically rigorous study by Tabellini (2010) demonstrates that among the richest set of countries in Europe, individualism, as measured by confidence in individual self-determination, has a positive causal effect on regional economic development. Although in this article I do not test the links between economic development and individualism as such, the association between economic performance and individualised worldviews, and therefore individualised perceptions of poverty, is central to my hypothesis. The presented theoretical discussion and empirical evidence allows me to speculate that economic development is associated with the attitudes of socially mobile individuals towards poverty 
determinants, but it is also important that we do not ignore the measure of income distribution that might also have a direct effect on popular explanations of why some people are in need.

We cannot ascertain how income inequality is associated with perceptions of popular explanations of poverty as existing theoretical framework and empirical findings provide mixed evidence on this association. On the one hand, the high levels of socio-economic disparities might be reflected in increased sensitivity to social inequality with the resultant attitudes towards structural explanations of poverty (Bucca, 2016) and stronger redistribution preferences (Meltzer \& Richard, 1981). On the other hand, income inequality on the national level might be more difficult to perceive than individuals' own socio-economic conditions, and even if they do understand the extend of income inequality, individuals might justify the existing disparities in the distribution of economic rewards as just (Lepianka et al., 2010; Shepelak \& Alwin, 1986). The effect of income inequality of popular explanations of poverty might be even more complicated in post-socialist societies. From the beginning of the 1990s, the growing levels of income inequality in these countries were mainly driven by two components of economic liberalisation such as increasing differences in wage distribution in private and public sectors and reforms in social benefits (Milanovic, 1999). Because the mix of these measures varied across countries (see Gugushvili, 2015a), the association of income inequality with perception of popular explanations of poverty might not be uniform in post-socialist societies. Therefore, my second macro-level hypothesis only refers to the effect of economic development:

H3: The effect of intergenerational social mobility on attitudes towards the determinants of poverty is stronger in more economically developed societies than it is in less economically developed societies.

\section{Research Design}

For the empirical test of the hypotheses, I use two datasets: European Values Studies (EVS) and the Life in Transition Survey (LITS), which are analysed separately. Both of these surveys provide nationally representative samples and are widely used in comparative social research (see Cojocaru, 2014; De Regt, Smits, \& Mortelmans, 2012; Gugushvili, 2015a, b, 2016). Face-to-face interviews in each country were conducted using a representative, multistage random sample of the adult population. The total number of completed interviews stood at around 1500 and 1000 respondents per country, respectively, in EVS and LITS. Significant efforts were undertaken to guarantee high scientific quality standards and to ensure that the survey questions were appropriately standardised between countries. ${ }^{1}$

The 2008 wave of EVS (2010) provides detailed information on social origin as well as occupational attainment and is used when looking at links between objective social mobility and perceptions of popular explanations of poverty. I pool data for

\footnotetext{
1 For a more detailed description of EVS and LITS and regarding their methodological approaches, consult the following website (www.europeanvaluesstudy.eu) and report from EBRD (2010).
} 
all individuals of working age from 25 to 64 years in 20 Western European societies (Austria, Belgium, Cyprus, Denmark, Finland, France, Germany, Greece, Iceland, Ireland, Italy, Luxemburg, Malta, Netherlands, Norway, Portugal, Spain, Sweden, Switzerland, and the UK) and 21 post-socialist countries that were the part of the former socialist bloc (Albania, Armenia, Azerbaijan, Belarus, Bulgaria, Croatia, Czech Republic, Estonia, Georgia, Hungary, Latvia, Lithuania, FYR Macedonia, Moldova, Poland, Romania, Russia, Serbia, Slovak Republic, Slovenia, and Ukraine). LITS was conducted in 2010 and includes information on subjective social mobility (EBRD, 2010a). The same post-socialist societies are included in the pooled analysis, but the LITS dataset only includes five Western European countries-France, Germany, Italy, Sweden, and the UK. Overall, 40,501 and 20,405 individuals qualify in EVS and LITS samples, but after list-wise deletion of missing data 29,443 and 17,830 individuals remain for multivariate analysis. Most of missing data come from objective and subjective social mobility variables as described below, but I do not employ multiple imputation option to deal with data missingness mainly because only a few control variables are used in regression analysis.

\section{Dependent and Independent Variables}

The dependent variable of this article stems from the identical EVS and LITS question about the main causes of poverty among individuals. The exact answer options on a question about the main reason why some people are in need are: (1) because of laziness and lack of willpower (individual blame), (2) because they have been unlucky (individual fate), (3) it is an inevitable part of modern life (social fate), and (4) because of injustice in our society (social blame). According to the descriptive statistics in Table 1, the most frequently mentioned explanation of why people are in need is injustice in society. In the EVS study, about two-fifths of respondents believe that societal injustice is the main cause of poverty. In the LITS survey that was conducted after the most severe consequences of the economic crisis, more than half of the respondents believe that injustice is the main factor contributing to why some people are in need. Laziness and lack of willpower are the second most mentioned explanation why people are in need. In EVS, individual luck is the least salient poverty attribution, and its share is even lower in LITS.

The main independent variables employed in this article are intergenerational occupational mobility and respondents' subjective perception of social mobility. For objective social mobility, EVS gives information about the Standard International Socio-Economic Index of Occupational Status (ISEI). ISEI scores are generated from ISCO88 codes (ILO, 2010) that are in turn derived from the following survey questions: "What is/was the name or title of your main job?", "in your main job, what kind of work do/did you do most of the time?" (Ganzeboom \& Treiman, 1996). The main advantage of this schema is that it scales and hierarchically ranks occupations according to the average level of education and job earnings (Ganzeboom et al., 1992). There are several alternative ways to operationalise social mobility according to respondents' and their parents ISEI status. The most straightforward approach entails subtracting respondents' ISEI scores from their 
Table 1 Attitudes towards the most important reason why some people are in need, the patterns of objective and subjective mobility, and control variables. Source Author's calculations based on data from EVS (2010) and EBRD (2010b)

\begin{tabular}{lll}
\hline & $\begin{array}{l}\text { EVS } \\
\text { Share/mean (SD) }\end{array}$ & $\begin{array}{l}\text { LITS } \\
\text { Share/mean (SD) }\end{array}$ \\
\hline $\begin{array}{ll}\text { Dependent variable } \\
\text { Popular poverty explanations }\end{array}$ & \\
$\quad$ Laziness & $26.1 \%$ & $20.4 \%$ \\
Unlucky & $15.7 \%$ & $9.9 \%$ \\
$\quad$ Part modern progress & $21.6 \%$ & $19.4 \%$ \\
Injustice in society & $36.6 \%$ & $50.3 \%$ \\
Independent variable & & \\
Intergenerational social mobility & Objective & Subjective \\
Strongly downward & $7.9 \%$ & $8.3 \%$ \\
Downward & $16.3 \%$ & $21.9 \%$ \\
Non-mobile & $28.5 \%$ & $24.3 \%$ \\
Upward & $26.7 \%$ & $35.6 \%$ \\
Strongly upward & $20.7 \%$ & $9.9 \%$ \\
Controls & & \\
Female & $0.55(0.50)$ & $0.60(0.49)$ \\
Age & $44.3(11.3)$ & $44.3(11.4)$ \\
Education & $4.36(1.27)$ & $4.38(1.41)$ \\
Labour market & & \\
Employed & $68.2 \%$ & $59.3 \%$ \\
Unemployed & $9.8 \%$ & $12.9 \%$ \\
Student & $1.2 \%$ & $0.5 \%$ \\
Retired & $9.6 \%$ & $11.6 \%$ \\
Other & $11.3 \%$ & $15.6 \%$ \\
\hline & & \\
\hline & & \\
\hline
\end{tabular}

parents' ISEI scores, which provides a continuous measure of social mobility that then can be applied to various regression settings. LITS, however, only allows the investigation of the categorical social mobility variable; hence, for comparability concerns, I transformed the derived continuous variable through the subtraction of respondents' and their parents ISEI scores into a categorical measure of mobility with five potential outcomes. ${ }^{2}$

ISEI scores vary from 16 to 90 ; those respondents who stayed within -5 and 5 margin of change in intergenerational ISEI score are coded as non-mobile. This is a reasonable assumption because a \pm 5 change in ISEI score should not imply a consequential transformation of a respondent's occupational status. On the upper end of mobility, those who increased ISEI within a range of 6-20 and 21-72, respectively, were classified as upwardly mobile and strongly upwardly mobile.

\footnotetext{
${ }^{2}$ In the unreported analysis, I tentatively employed the described continues measure of social mobility, but the derived results were similar to those presented latter in this article.
} 
Those who had experienced a decrease within a margin of -6 to -20 and -21 to -72 , respectively, were classified as downwardly mobile and strongly downwardly mobile. The proportion of missing data for respondents' and their parents ISEI scores are 9.1 and $17.2 \%$, respectively. The missing rate varies across countries due to idiosyncratic characteristics of national surveys, but this is unlikely to cause systemic bias in the estimation of results (see GESIS, 2011).

Unlike EVS, social origin characteristics in LITS are restricted to parental education. This means that the LITS dataset does not allow for the calculation of measures of objective occupational mobility, but it includes a measure of subjective intergenerational mobility. LITS asks respondents whether they agree or disagree with the following statement: "I have done better in life than my parents". On a 5-point Likert scale, respondents can choose from "strongly disagree", "disagree", "neither disagree nor agree", "agree", and "strongly agree". Respondents are further instructed to compare their parents' position to their own when the former were at the same age as respondents at the time of the interview. I transform the answers from this question into five categorical variables: strongly disagree $=$ strongly downwardly mobile, disagree $=$ downwardly mobile, neither disagree nor agree $=$ non-mobile, agree $=$ upwardly mobile, and strongly agree $=$ strongly upwardly mobile. Information on subjective mobility is not available for only $4.3 \%$ of respondents. Table 1 depicts the distribution of objective and subjective social mobility. The main difference between these two modes of social mobility is that individuals in LITS sample are less likely to describe themselves as strongly upwardly mobile than individuals in EVS sample who have experienced objective upgrading in occupation status.

\section{Control Variables}

I account for the identical control variables in the analysis of the effects of objective and subjective social mobility on perceptions of popular explanations of poverty. In the main analysis, control variables are limited to basic demographic and labour market characteristics. The robustness check of the baseline models, described in the results section, however, includes additional control variables. I employed an array of socio-demographic variables that are expected to be associated with the dependent variable: female, age, and age squared of respondents. The highest level of completed education is based on the 1997 version of International Standard Classification of Education (ISCED) from pre-primary $=1$ to the second stage of tertiary education $=7$. Dummy variables for the following types of labour market status were created: employed, unemployed, students, retired, and other labour market status which serves as a reference category. Country fixed effects are used, where appropriate, to account for country-specific characteristics in regression models. Table 1 suggest that LITS dataset that includes more post-socialist societies has a slightly higher share of female and a lower share of employed individuals due to male household members being away and the higher unemployment rates (EBRD, 2010b). There are virtually no missing data for respondents' gender, age, and education, while for employment characteristics, data are missing for about 0.5 and $0.1 \%$ of individuals, respectively, in EVS and LITS. 


\section{Macro-level Variables}

To account for the post-socialist legacy, I create a dummy variable for all countries of the former socialist bloc. To test the effect of economic development, I use GDP per capita based on purchasing power parity (PPP). Data are in constant 2005 international dollars and are derived from the World Bank's (2015) World Development Indicators (WDI) database. Using the PPP-adjusted GDP indicator is necessary because it allows cross-national comparison of economic development. The descriptive statistics for this variable indicates that Western European countries are much richer (mean GDP PPP capita USD 34.9 thousand [SD 10.7] in 2008 and USD 37.0 thousand [SD 2.6] in 2010) than post-socialist societies (mean GDP PPP capita USD 15.2 thousand [SD 7.1] in 2008 and USD 16.3 thousand [SD 6.9] in 2010), but within both groups, we observe significant variation in economic development. Among various indicators of income inequality, the Standardised World Income Inequality Database (SWIID) seems to be the most appropriate for comparative research (Solt, 2009). I use net Gini coefficients that show how the real disposable incomes were distributed in these societies. The descriptive data suggest that that by the end of 2000s, the mean Gini coefficient in Western European countries was lower (mean Gini 0.29 [SD 0.03] in 2008 and 0.30 [SD 0.05] in 2010) than in post-socialist societies (mean Gini 0.32 [SD 0.06] both in 2008 and 2010).

\section{Methods}

The survey question investigating perceptions of why some people are in need includes categorical answer options that are best understood using multinomial logistic models. Alternatively, for the robustness check of the latter method, I also run linear probability models with binary dependent variables for each considered poverty attribution. The results of this exercise were largely similar to the findings that are reported in Results section, which increases my confidence in the appropriateness of multinomial logistic approach. Model 1, shown below, is a general regression fitted to observe associations between social mobility and the dependent variables. The baseline models control for gender, age, age $^{2}$, education, labour market status, and country fixed effects. Robust standard errors are clustered around countries.

$$
\begin{aligned}
& \text { Perceptions of popular explanations of poverty }{ }_{i} \\
& =\beta_{0}+\beta_{1} \text { gender }_{i}+\beta_{2} \text { age }_{i}+\beta_{3} \text { education }_{i} \\
& +\beta_{4} \text { labour market status }_{I}+\beta_{5} \text { country dummies }_{i} \\
& +\beta_{6} \text { objective/ } \text { subjective social mobility }_{i}+\varepsilon_{i j}
\end{aligned}
$$

The main results are presented in predictive margins for individuals' different social mobility experiences. The ability to present results in predicted probabilities is one of the main advantages of using multinomial logistic models for testing Hypothesis 1 instead of multilevel multinomial regressions. The latter are used in the empirical section to test Hypotheses 2 and 3 which imply that macro-level contextual environment moderates the effect of social mobility on attitudes towards 
poverty explanations. I employ multilevel multinomial regression models that consist of level 1 individual analysis and level 2 country contextual characteristics of the legacy of socialist system, economic development, and income inequality, and their cross-level interactions with objective and subjective social mobility. Model 2 formally outlines the analytical strategy.

Perceptions of popular explanations of poverty

$$
\begin{aligned}
= & \overbrace{\text { Model 1 }}+\gamma_{1} \text { post-socialism }_{j} \\
& +\gamma_{2} \text { economic development }_{j}+\gamma_{3} \text { income inequality }_{j} \\
& +\sum_{\mathrm{l}=1}^{3} \eta_{1}\left({\text { objective } / \text { subjective social mobility }_{i j}}\right. \\
& \left.*\left(\text { post-socialism }_{j}+\text { economic development }_{j}+\text { income inequality }_{j}\right)\right)
\end{aligned}
$$

The cross-level interaction effects $\eta_{1}$ indicate how contextual variables moderate the relationship between intergenerational mobility and attitudes towards poverty determinants. Multilevel analysis is performed in the Stata 13 statistical package with the help of "gllamm" command's multinomial function from its binomial family of regressions. Because the interpretation of interaction terms in regression models is often misleading (Brambor, Clark, \& Golder, 2006), I graphically illustrate the marginal effect of social mobility and the corresponding standard errors across a substantively meaningful range of the main contextual variablesthe post-socialist legacy and economic development.

\section{Results}

\section{Multivariate Analysis}

Based on the theoretical framework and Hypotheses 1, I expect that downwardly mobile individuals are more likely to believe that external factors such as injustice in society are the main determinants of poverty, while upwardly mobile individuals should consider factors controlled by the individual such as laziness and a lack of willpower to be more decisive determinants of life chances. Table 2 displays the predicted margins of the corresponding explanations of poverty and their $95 \%$ confidence intervals (CI) for upwardly mobile, downwardly mobile, and non-mobile individuals. McFadden's pseudo- $R^{2}$ in models on both objective and subjective social mobility explains about $5 \%$ of variation in the dependent variable. The unreported marginal effects for control variables are in line with the previous scholarship on covariates of perceptions of popular explanations of poverty. Females are less likely to declare laziness and inevitability of life as explanations of poverty, while they are more likely to select social injustice. The age of respondents is negatively associated with the perception of laziness as the main cause of poverty. More educated individuals have a lower probability of choosing laziness but are more likely to name inevitability of modern life as an explanation of poverty. For subjective mobility, the better educated are also less likely to name injustice in 
Table 2 Objective and subjective social mobility and attitudes towards the most important reason why some people are in need. Source Author's calculations based on data from EVS (2010) and EBRD (2010b)

\begin{tabular}{|c|c|c|c|c|}
\hline & 1. Laziness & $\begin{array}{l}\text { 2. They were } \\
\text { unlucky }\end{array}$ & $\begin{array}{l}\text { 3. Inevitability of } \\
\text { life }\end{array}$ & $\begin{array}{l}\text { 4. Injustice in } \\
\text { society }\end{array}$ \\
\hline \multicolumn{5}{|l|}{ Objective mobility } \\
\hline $\begin{array}{l}\text { Strongly } \\
\text { downward }\end{array}$ & $0.25(0.23-0.27)$ & $0.15(0.14-0.17)$ & $0.22(0.20-0.23)$ & $0.38(0.36-0.40)$ \\
\hline Downward & $0.26(0.25-0.27)$ & $0.14(0.13-0.15)$ & $0.23(0.22-0.24)$ & $0.36(0.35-0.38)$ \\
\hline Non-mobile & $0.26(0.25-0.27)$ & $0.15(0.14-0.16)$ & $0.22(0.22-0.23)$ & $0.36(0.35-0.37)$ \\
\hline Upward & $0.26(0.25-0.27)$ & $0.16(0.15-0.17)$ & $0.22(0.21-0.23)$ & $0.36(0.35-0.37)$ \\
\hline Strongly upward & $0.27(0.26-0.28)$ & $0.15(0.14-0.16)$ & $0.23(0.22-0.25)$ & $0.34(0.33-0.35)$ \\
\hline \multicolumn{5}{|l|}{ Subjective mobility } \\
\hline $\begin{array}{l}\text { Strongly } \\
\text { downward }\end{array}$ & $0.16(0.14-0.18)$ & $0.08(0.07-0.10)$ & $0.16(0.14-0.19)$ & $0.59(0.56-0.62)$ \\
\hline Downward & $0.16(0.15-0.17)$ & $0.10(0.09-0.11)$ & $0.19(0.17-0.21)$ & $0.55(0.53-0.57)$ \\
\hline Non-mobile & $0.19(0.18-0.20)$ & $0.11(0.10-0.11)$ & $0.19(0.18-0.21)$ & $0.51(0.50-0.53)$ \\
\hline Upward & $0.23(0.22-0.24)$ & $0.10(0.09-0.10)$ & $0.20(0.19-0.21)$ & $0.47(0.46-0.49)$ \\
\hline Strongly upward & $0.27(0.25-0.29)$ & $0.10(0.08-0.11)$ & $0.20(0.17-0.22)$ & $0.44(0.41-0.47)$ \\
\hline
\end{tabular}

Models control for respondents' age, age ${ }^{2}$, gender, education, and labour market status, and country fixed effects

Predictive margins (with 95\% confidence intervals) from multinomial logistic models

society than inevitability of modern life as a determinant of poverty. Furthermore, unemployed tend to disregard lack of willpower but emphasise the role of social injustice, while the opposite association is observed for employed individuals.

Now I move specifically to testing Hypotheses $1 \mathrm{a}$ and $1 \mathrm{~b}$. The upper half of Table 2 shows the association of the various categories of occupational mobility with the attributes of poverty. Overall, we do not see any statistically significant links between objective social mobility and the dependent variable of this study. The only instance for which social mobility experience has some association with attitudes towards poverty determinants is shown in Column 4. In line with Hypothesis 1b, strongly upwardly mobile individuals are marginally less likely to explain poverty with social injustice (0.34, CI 95 0.33: 0.35$)$ when compared to strongly downwardly mobile individuals (0.38, CI 95 0.36: 0.40).

The lower half of Table 2 shows the association between subjective perception of mobility and perceptions of popular explanations of poverty. The results confirm Hypothesis 1 regarding subjective perception of mobility and its association with attitudes towards the determinants of poverty. In Column 1, we can observe strong links between subjective mobility and thinking that laziness and lack of willpower are responsible for why people are in need. In line with Hypothesis 1a, the strongly upwardly mobile group exhibits much higher chances of selecting this category of poverty attribution $(0.27$, CI $950.25: 0.29)$ than do non-mobile $(0.19$, CI 950.18 : $0.20)$ and downwardly mobile $(0.16$, CI 95 0.14: 0.18) individuals. The association of subjective perception of mobility with the answer option on the role of luck in 
poverty is less clear. In Column 2, we observe an inverse U-shape effect. Both strongly downward (0.08, CI 95 0.07: 0.10) and upward (0.10, CI 95 0.09: 0.10) mobile individuals are less likely to claim that the poor have been unlucky than do non-mobile individuals (0.11, CI 95 0.10: 0.11).

As regards the association between subjective perception of mobility and believing that poverty is an inevitability of modern life, in Column 3 it is positive and linear, but this effect is statistically significant only for strongly downwardly mobile (0.16, CI 95 0.14: 0.19) individuals as opposed to that for upwardly mobile individuals (0.20, CI 95 0.19: 0.21). Lastly, the clearest trend which emerges from Table 2 is the association between subjective social mobility and perceiving social injustice as the poverty determinant-Hypothesis $1 \mathrm{~b}$. Those individuals who declare that they have experienced upward social mobility are significantly less likely to think that injustice in society is to be blamed for people being in need. For instance, non-mobile individuals are predicted to have a 51.2\% (CI 95 49.8: 52.6) chance of selecting this poverty attribution, while for the strongly upwardly mobile group, this effect is about 7 percentage points lower (44.1, CI 95 41.4: 46.8). Furthermore, strongly downwardly mobile individuals have about 0.59 (CI 95 0.56: 0.62) probability of choosing social injustice as the primary poverty explanation. Overall, it seems that subjective social mobility experience is indeed associated with assigning poverty to individual and socio-structural explanations, while objective mobility is not.

In order to check the robustness of the findings in Table 2, I run the described models with an additional array of control variables that can potentially cancel out or strengthen the observed association of social mobility with popular poverty explanations (see Habibov, 2011; Kreidl, 2000; Smith \& Matějů, 2012; Tooth \& Mishra, 2013). For objective intergenerational mobility these variables are: the size of the town where the interviews were conducted, parental education, respondents' occupational social class in the Erikson-Goldthorpe (EGP) class schema, and monthly household income corrected for PPP in Euros. For subjective social mobility, the following variables were added as additional controls: respondents' type of settlement, parental education, respondents' occupational attainment grouped into white collar, blue collar, service, and farming occupational groups, and the current socio-economic rung of respondents' household on a ten-ladder social hierarchy. After introducing the listed variables in multinomial logistic models, the scale of the point estimates is marginally amended, but the substantive and statistical significance observed in the main results remains unaffected. Objective mobility remains an insignificant covariate of the dependent variable, while subjective mobility is a strong predictor of perceptions of popular explanations of poverty.

\section{Multilevel Analysis}

I start multilevel analysis with multilevel multinomial models in Table 2 that account for respondents' individual-level characteristics and macro-level variables on the socialist legacy, economic development, and income inequality. I only include dummy variables for upward and strongly upward mobility. In the latter 
specification, which simplifies the presentation of the cross-level interaction effects, the reference category consists of downwardly and non-mobile individuals.

The results shown in odds ratios for objective mobility in Model 1, Table 3, suggest that once country-level variables and other individual-level controls are accounted for, strongly upwardly mobile individuals are $1.15(p<0.01)$ and 1.09 $(p<0.05)$ more likely to name laziness and inevitability of life as explanations of poverty when compared to social injustice. These effects are much more pronounced for subjective mobility in Model 2 in which both upward and strong upward mobility is associated with a higher likelihood of selecting laziness (1.57, $p<0.01$ and 1.94, $p<0.01)$ and individuals' luck $(1.20, p<0.01$ and 1.29, $p<0.01)$. Furthermore, all three contextual variables are associated with the selection of specific explanations of poverty. In Model 1, individuals in postsocialist societies are significantly less likely to explain poverty as the result of luck $(0.85, p<0.01)$ and inevitability of modern life $(0.63, p<0.01)$ when compared to social injustice. For subjective mobility in Model 2, individuals in countries with high economic development are more likely to explain poverty with luck and inevitability of life. In Model 1, GDP PPP per capita and the level of income inequality are also associated with selecting laziness and lack of willpower as an explanation of poverty, while in Model 2 the latter two contextual variables are, respectively, positively and negatively associated with the lower propensity of selecting luck as the main poverty attribute.

For testing Hypotheses 2 and 3, we have to look at the interaction effects between social mobility and contextual variables in Table 4 . Because an interpretation of the main effects of interaction terms in regression models is often deceptive, for now I only concentrate on the substantive and statistical significance of the presented cross-level interactions. For objective mobility in Model 1, the results suggest that socially mobile individuals in more unequal societies are less likely to declare that poverty is the result of inevitability of life or individuals' bad luck than that poverty is caused by social injustice. Since the earlier research suggests that the level of social mobility is negatively associated with income inequality (see Andrews \& Leigh, 2009; Jerrim \& Macmillan, 2015), perhaps mobile individuals in countries with high Gini coefficients are more aware of the structural conditions that hinder their fellow citizens' life chances. More telling cross-level interaction effects are observed in Model 2. The results provide evidence that subjectively upwardly mobile individuals in post-socialist societies are significantly more likely to explain poverty as a consequence of individuals' laziness and lack of willpower (for the upwardly mobile OR is $1.5, p<0.05$ ), inevitability of life (for the strongly upwardly mobile OR is $2.7, p<0.05$ ), and bad luck (for the strongly upwardly mobile OR is $3.2, p<0.01$ ) rather than injustice in society.

The second significant effect which we see in Model 2 (Table 4) is that, as Hypothesis 3 suggests, a statistically significant association exists between economic development and the effect of social mobility on the perception of poverty attributes. First, the values of the interaction terms in Column III between GDP PPP per capita and upward mobility (OR 1.2, $p<0.05$ ) and strong upward mobility (OR 1.6, $p<0.01$ ) indicate that in more economically affluent societies, upwardly mobile individuals are more likely to declare luck as the main explanation 


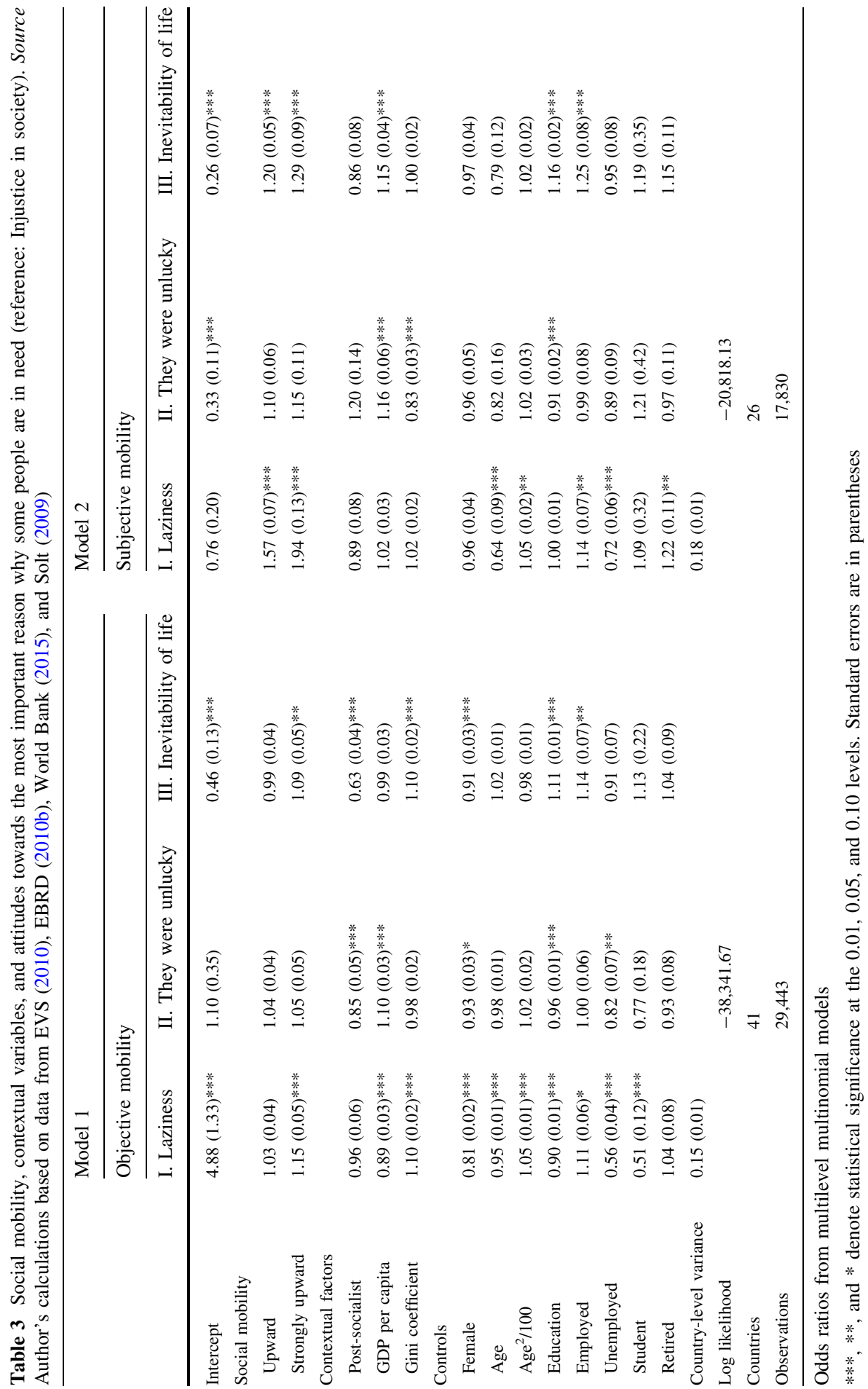




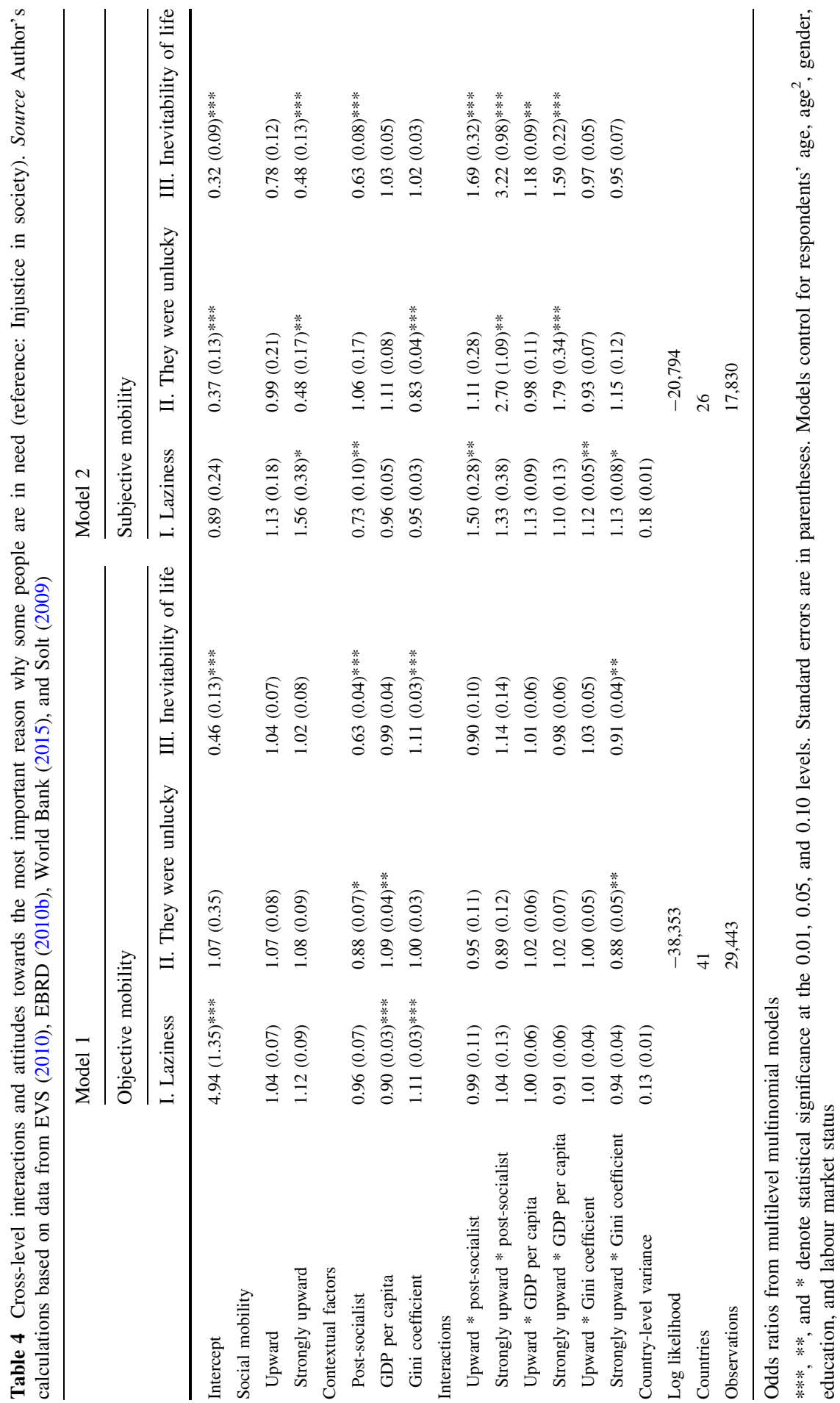


of poverty than social injustice. The corresponding interaction coefficient in Column II reveals that strong upward mobility is associated with selecting inevitability of life as an explanation of why some people are in need. In Column I, Model 2, we also observe that upwardly mobile individuals in countries with higher income inequality are more likely to choose laziness as the main attribute of poverty.

\section{Specific Effects of Post-socialism and Economic Development}

As already mentioned, the direction and substantive significance of interaction effects in nonlinear models cannot always be determined by examining regression coefficients (see Karaca-Mandic, Norton, \& Dowd, 2012). This is why I plot interaction effects between subjective social mobility, the legacy of post-socialism, and specific values of GDP PPP per capita. Figure 1(1) depicts marginal effects for upward and strong upward mobility on the likelihood of preferring specific explanation of poverty in post-socialist and other considered societies. We can see that subjectively upwardly mobile individuals in post-socialist countries in comparison with non-mobile individuals have significantly higher propensity to select laziness and lack of willpower (0.08, CI 95 0.05: 0.10) than mobile individuals in Western welfare democracies (0.02, CI 95: 0.01: 0.03). Furthermore, Fig. 1c suggests that individuals who define themselves as upwardly mobile have significantly lower propensity to select injustice in society as the main explanation why some people are poor in post-socialist countries $(-0.08$, CI $95-0.10:-0.06)$ than in other societies included in the analysis (-0.01, CI $95-0.03$ : 0.01).

In Fig. 1(2), I plot the effects of various GDP PPP per capita values on the association between social mobility and perceptions of popular explanations of poverty. The range of economic development from USD 5000 to USD 25,000 covers post-socialist societies, while the value of USD 35,000 is close to the mean level of economic development in the analysed five Western European democracies. Figure 1(2a) suggests that upwardly mobile individuals in countries with low GDP PPP per capita levels such as Moldova and Georgia are predicted to be about $1 \%$ (CI 95 0.28: 1.49) more likely than non-mobile and downwardly mobile individuals to prefer laziness and the main poverty explanation, while this effect is about $6 \%$ (CI 95 2.30: 8.79) in countries with GDP PPP per capita level of about USD 25,000 such as Slovakia and Czech Republic. On the other hand, in countries with GDP PPP per capita of more than USD 20,000 strongly upwardly mobile individuals are about 6\% (CI 95 -7.34: -4.03) less likely than downward and non-mobile individuals to select injustice in society as the main poverty attribute. This effect is non-significant in countries with a low level of economic development of about USD 10,000 PPP per capita such as Albania or Ukraine. The results presented in Fig. 1(2) also indicate that the moderating effect of economic development is insignificant in the most affluent societies of our sample, all of which are Western welfare democracies.

Although I identified that in post-socialist societies among socially mobile individuals, perceptions of popular explanations of poverty vary when compared to other countries, the findings of the study using a sample of 21 post-socialist nations might differ if separate country groups are analysed. There are major differences 

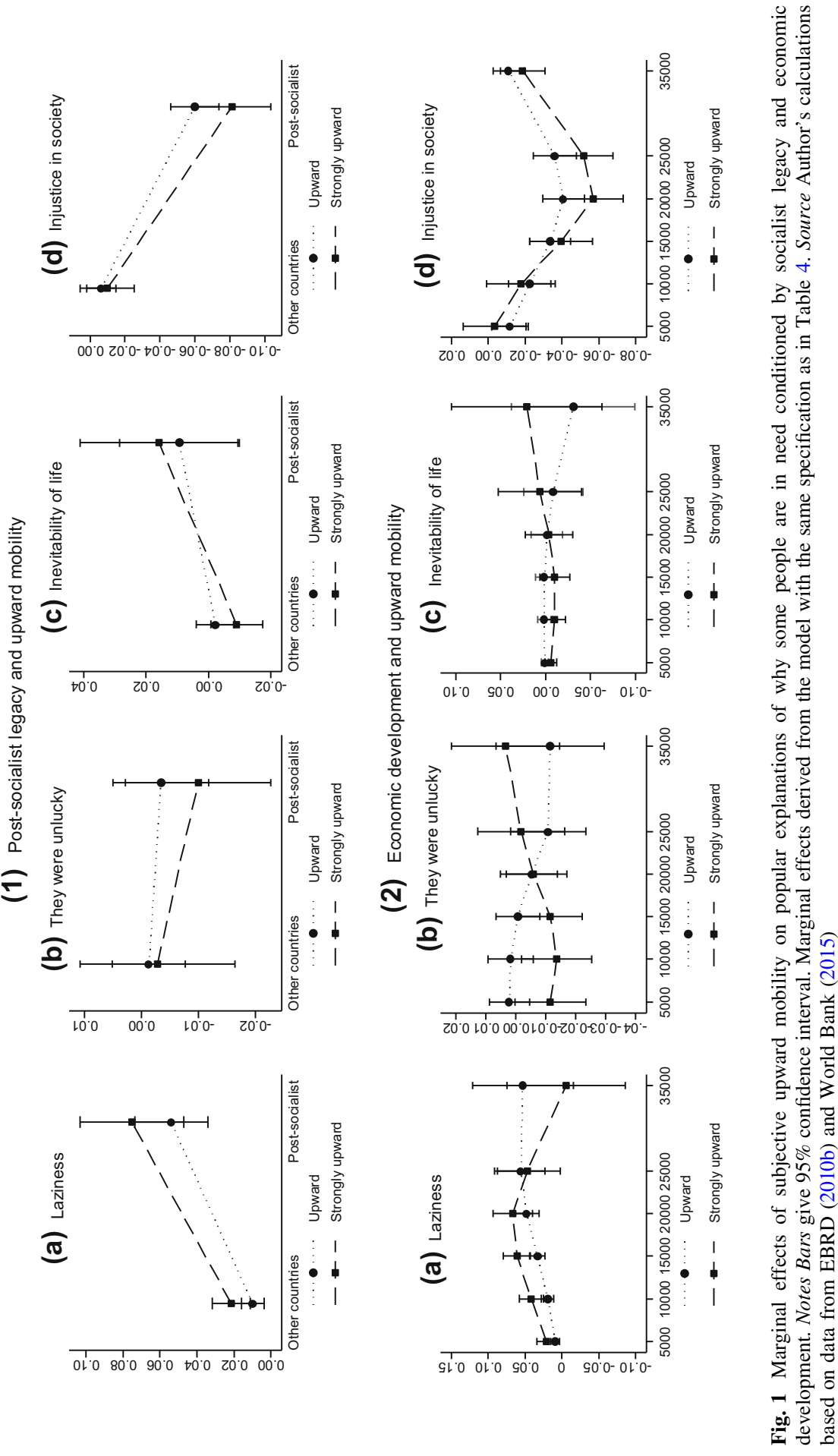
between post-socialist societies both in the geographical location and their histories and cultural proximity to the European tradition and the degree to which they were dependent on the Soviet Union with the corresponding autonomy of tolerating private property and entrepreneurship (Gijsberts, 2002), all of which can affect perceptions of popular explanations of poverty. Furthermore, available evidence suggests that public beliefs regarding the causes of poverty significantly diverge within post-socialist countries (Habibov, 2011; Murthi \& Tiongson, 2009). There have been attempts to incorporate post-socialist societies into a welfare state typology (Aidukaite, 2009; Fenger, 2007; Gugushvili, 2010, 2015b) and the varieties of capitalism frameworks (Adam, Kristan, \& Tomšic, 2009; Bohle \& Greskovits, 2012). The problem with using the latter classifications is that they generally cover only a small portion of the countries. In addition, the links between these approaches, social mobility regimes, and perceptions of popular explanations of poverty are not clear.

To understand the observed differences in the effect of social mobility in specific groups of post-socialist societies, I use a categorisation derived from the annual Transitional Reports of the European Bank for Reconstruction and Development (EBRD), in which economic reforms are described separately in (1) Central Europe and the Baltic states-Czech Republic, Estonia, Hungary, Latvia, Lithuania, Poland, Slovak Republic, and Slovenia; (2) South-Eastern Europe-Albania, Bulgaria, Croatia, Macedonia, Romania, and Serbia; and (3) non-Baltic former Soviet Union-Armenia, Azerbaijan, Belarus, Georgia, Moldova, Russia, and Ukraine. In the unreported analysis (available upon request), I interacted coefficients between upward social mobility and specific post-socialist country groups derived from models which are identical to those shown in Table 4. The results suggest that the differences found between country groups are not salient. It seems, however, that the strongest effect of social mobility is observed in Central European post-socialist societies where both upward and strongly upwardly mobile groups are more likely to select the option on inevitability of life rather than social injustice as the main poverty explanation. It might be a possibility that mobile individuals in the countries of Central Europe and the Baltic region are different from mobile individuals in other post-socialist societies due to their varying exposure to communism and the resultant differences in individualistic attitudes.

\section{Discussion}

In this article, I analysed how social mobility experience associates with perceptions of popular explanations of poverty. My micro-level hypothesis implied those who experience upward social mobility are more likely than non-mobile individuals to make internal dispositions that are reflected in attitudes towards the determinants of poverty. It is assumed that individuals start with an initial set of attitudes that are amended according to their personal experience of social mobility and the selfserving bias in perceptions about the role of ascribed and attained factors related to success or failure. I also looked on the consequences of both objective and subjective social mobility for the perceptions of poverty determinants. 
In line with the proposed hypotheses, substantive results demonstrate that downwardly mobile individuals are more likely and upwardly mobile less likely, to explain poverty by external factors such as societal injustice. One of the central findings of this article is that what really matters in the formation of attitudes is not an objective occupational upgrade which conventionally measures social mobility in the social stratification literature, but rather how people perceive their own mobility experience. This is well aligned with an observation made by Lipset (1992) that subjective feelings about mobility are more important for political attitudes than objective intergenerational upgrade of occupational status. The same findings have been reported in the earlier literature on status inconsistency (Baer, Eitzen, Duprey, Thompson, \& Cole, 1976). Psychological explanations of this tendency are that individuals tend to filter their objective environment in order to derive their subjective perceptions of the world and their own experiences (Wolf, 1978). Furthermore, inconsistencies between subjective perception of mobility and objective mobility experience might be attributed to people's tendency to consider their own success in broader terms than occupational attainment. In a study conducted in France, when asked whether labour market status was the main feature of their life success, more than half of the respondents provided a negative answer (Duru-Bellat \& Kieffer, 2008).

Nonetheless, the employed data and methods do not allow us to unequivocally assert that the observed associations are the result of the self-serving bias in causal attribution mechanism. We cannot exclude the possibility of reverse causation in the reported association as attitudes towards poverty explanations might affect individuals' social mobility experience. EVS and LITS are separate surveys, conducted at different times. They are not longitudinal datasets and do not allow for the following of individuals across their life courses for detecting the effect of social mobility. It could be that upwardly mobile individuals had the same attitudes before they experienced mobility and that individualistic personalities helped them to succeed in life. Although I cannot address this problem, most of the existing studies on the consequences of intergenerational social mobility face similar constraints. Furthermore, the findings from several longitudinal and experimental studies suggest that changes in attitudes do occur over time and along with individuals' real or perceived social mobility experiences (Clark \& D'Angelo, 2010; Marshall \& Firth, 1999; Shariff, Wiwad, \& Aknin, 2016).

Next, with the outlined macro-level hypotheses, I expected that people from postsocialist societies and more economically developed economies are more likely than people from other European and economically less prosperous societies to explain performance by factors that are internal to themselves. Based on the previous research and judgement of some of the leading scholars of social thought, I made an assumption that societies with the legacy of socialism and countries with the advanced level of economic development both have a high propensity to individualise hardship. Socially mobile individuals are therefore more likely to attribute failure to self-determining factors. My findings indicate that the socialist legacy and economic development indeed significantly moderate the effect of subjective social mobility on the perception that poverty is caused by laziness or societal injustice. It might be true that in affluent societies people are more likely to 
believe that everyone has a high opportunity for success, but this does not explain why differences between mobile and non-mobile individuals vary cross-nationally. With the utilised data and methods, nonetheless, it is problematic to assert that the considered macro-level factors are causally responsible for the diverse implications of social mobility on perceptions of popular explanations of poverty.

The findings of this study could contribute to the theoretical development of the social justice research. For instance, the social bases of support for certain distributive principles is well acknowledged by scholars in justice area (Deutsch, 1975; Lewin-Epstein, Kaplan, \& Levanon, 2003; Shirazi \& Biel, 2005), but they do not usually consider the role of life-long learning. Individuals acquire values and beliefs at a relatively young age when they are entering adulthood from the content of formal and informal education, the distinctive developments of their birth cohorts through peer group socialisation, and idiosyncratic historical experiences such as war, revolution, or mass migration (Jennings \& Markus, 1984; Ryder, 1965). Nonetheless, socially mobile individuals, by virtue of moving to a higher or a lower social class, acquire new values and preferences similar to those of the destination class (De Graaf, Nieuwbeerta, \& Heath, 1995). The field of social justice research would benefit to acknowledge that the values of intergenerationally mobile individuals are affected by interaction with individuals from the host class and reflect the values of this normative reference group (Heath, Jowell, \& Curtice, 1985), but this acquisition is likely to happen gradually, in a process that Blau (1956) refers to as the "pattern of acculturation".

Lastly, assuming that the results of this study at least partially reflect reality, it is interesting to consider the implications of social mobility for public and social policies and political and economic systems. My answer to the question can be only speculative. First, it is known that the levels of objective social mobility across countries do not dramatically vary (Breen, 2004; Gugushvili, 2014), and, as I find in the current article, this type of mobility does not exert a particularly strong association with attitudes, whereas subjective social mobility has much stronger links with attitudes towards the determinants of poverty. Subjective experience of intergenerational mobility might be particularly relevant in post-socialist societies because the economic recession of the 1990s generated much stronger changes in the perception of subjective mobility than was the case in terms of objective occupational mobility. It is also known that subjective social mobility is closely related to an individual's current socio-economic status (Kelley \& Kelley, 2009). The latter might imply that in more economically developed societies, socially mobile individuals are less likely to support income distribution and policies that help the poor. Therefore, social mobility and resultant attitudes about poverty can create a vicious circle in which an increase in the former leads to more negative perceptions of people in need. The latter can be an exciting topic for future longitudinal and experimental research on the link between intergenerational social mobility and social justice.

Acknowledgements The author is thankful to the Editors of Social Justice Research, four anonymous reviewers, Fabrizio Bernardi, Martin Kohli, Ellu Saar, Martin Whyte, Mandi Larsen, Alexander SchmidtCatran, Katrin Prinzen and the participants of the 1st BIGSSS International Conference "Social 
Stratification and Social Policy", the 4th International Annual Research Conference "Cultural and Economic Changes under Cross-National Perspective", and the 12th Conference of the European Sociological Association "Differences, Inequalities and Sociological Imagination" for valuable feedback on an earlier versions of this article.

Funding The article was partially prepared within the framework of a subsidy granted to the HSE by the Government of the Russian Federation for the implementation of the Global Competitiveness Program. This study was partially funded by the Postdoctoral Fellowship of the Bremen International Graduate School of Social Sciences (BIGSSS) and the Postdoctoral Research Fellowship in South Caucasus Studies at the Russian and Eurasian Studies Centre of St. Antony's College, University of Oxford, in association with the Academic Swiss Caucasus Net (ASCN) at the University of Fribourg, Switzerland.

\section{Compliance with Ethical Standards}

Conflict of interest Alexi Gugushvili declares that he has no conflict of interest.

Ethical Approval This article does not contain any studies with human participants or animals performed by any of the authors.

Open Access This article is distributed under the terms of the Creative Commons Attribution 4.0 International License (http://creativecommons.org/licenses/by/4.0/), which permits unrestricted use, distribution, and reproduction in any medium, provided you give appropriate credit to the original author(s) and the source, provide a link to the Creative Commons license, and indicate if changes were made.

\section{References}

Adam, F., Kristan, P., \& Tomšič, M. (2009). Varieties of capitalism in Eastern Europe (with special emphasis on Estonia and Slovenia). Communist and Post-Communist Studies, 42(1), 65-81. doi:10. 1016/j.postcomstud.2009.02.005.

Aidukaite, J. (2009). Old welfare state theories and new welfare regimes in Eastern Europe: Challenges and implications. Communist and Post-Communist Studies, 42(1), 23-39. doi:10.1016/j. postcomstud.2009.02.004.

Alesina, A., \& Glaeser, E. (2004). Fighting poverty in the US and Europe. A world of difference. Oxford: Oxford University Press.

Alston, P. J., \& Dean, K. I. (1972). Socioeconomic factors associated with attitudes toward welfare recipients and the causes of poverty. Social Service Review, 46(1), 13-23. doi:10.2307/30021866.

Andrews, D., \& Leigh, A. (2009). More inequality, less social mobility. Applied Economics Letters, 16(15), 1489-1492. doi:10.1080/13504850701720197.

Atal, Y. (Ed.). (1999). Poverty in transition and transition in poverty: Recent developments in Hungary, Bulgaria, Romania, Georgia, Russia and Mongolia. New York: Berghahn Books.

Baer, L., Eitzen, D. S., Duprey, C., Thompson, N. J., \& Cole, C. (1976). The consequences of objective and subjective status inconsistency. The Sociological Quarterly, 17(3), 389-400. doi:10.1111/j. 1533-8525.1976.tb00992.x.

Ball, R. (2001). Individualism, collectivism, and economic development. The Annals of the American Academy of Political and Social Science, 573(1), 57-84. doi:10.1177/000271620157300104.

Blau, P. M. (1956). Social mobility and interpersonal relations. American Sociological Review, 21(3), 290-295. doi:10.2307/2089282.

Blau, P. M., \& Duncan, O. D. (1967). The American occupational structure. New York: Wiley.

Bohle, D., \& Greskovits, B. (2012). Capitalist diversity on Europe's periphery. Ithaca: Cornell University Press.

Brambor, T., Clark, W. R., \& Golder, M. (2006). Understanding interaction models: Improving empirical analyses. Political Analysis, 14(1), 63-82. doi:10.1093/pan/mpi014.

Breen, R. (Ed.). (2004). Social mobility in Europe. Oxford; NY: Oxford University Press. 
Breznau, N. (2016). Positive returns and equilibrium: Simultaneous feedback between public opinion and social policy. Policy Studies Journal. doi:10.1111/psj.12171.

Bucca, M. (2016). Merit and blame in unequal societies: Explaining Latin Americans' beliefs about wealth and poverty. Research in Social Stratification and Mobility, 44, 98-112. doi:10.1016/j.rssm. 2016.02.005.

Burger, J. M. (1981). Motivational biases in the attribution of responsibility for an accident: A metaanalysis of the defensive-attribution hypothesis. Psychological Bulletin, 90(3), 496-512. doi:10. 1037/0033-2909.90.3.496.

Clark, A., \& D'Angelo, E. (2010). Upward social mobility, well-being and political preferences: Evidence from the BHPS. Working Paper, Nr. 338 (Report). Ancona: Universitá Politecnica delle Marche.

Cojocaru, A. (2014). Prospects of upward mobility and preferences for redistribution: Evidence from the Life in Transition Survey. European Journal of Political Economy, 34, 300-314. doi:10.1016/j. ejpoleco.2014.03.003.

Crocker, J., \& Park, L. E. (2004). The costly pursuit of self-esteem. Psychological Bulletin, 130(3), 392-414. doi:10.1037/0033-2909.130.3.392.

De Graaf, N. D., Nieuwbeerta, P., \& Heath, A. (1995). Class mobility and political preferences: Individual and contextual effects. American journal of sociology, 100(4), 997-1027. doi:10.2307/ 2782158.

De Regt, S., Smits, T., \& Mortelmans, D. (2012). The relevance of class in shaping authoritarian attitudes: A cross-national perspective. Research in Social Stratification and Mobility, 30(3), 280-295. doi:10. 1016/j.rssm.2012.03.001.

Deutsch, M. (1975). Equity, equality, and need: What determines which value will be used as the basis of distributive justice? Journal of Social Issues, 31(3), 137-149. doi:10.1111/j.1540-4560.1975. tb01000.x.

Duru-Bellat, M., \& Kieffer, A. (2008). Objective/subjective: The two facets of social mobility. Sociologie du Travail, 50, e1-e18. doi:10.1016/j.soctra.2008.07.001.

EBRD. (2010a). Life in Transition Survey. Aggregated database. London: European Bank for Reconstruction and Development.

EBRD. (2010b). Life in transition: After the crisis. London: European Bank for Reconstruction and Development.

Erikson, R., \& Goldthorpe, J. H. (1992). The constant flux: A study of class mobility in industrial societies. New York; Oxford: Clarendon Press; Oxford University Press.

Evans, M. D. R., \& Kelley, J. (2004). Subjective social location: Data from 21 nations. International Journal of Public Opinion Research, 16(1), 3-38. doi:10.1093/ijpor/16.1.3.

EVS. (2010). European values study 2008, 4th wave, integrated dataset. Cologne: Online Database, GESIS Data Archive. doi:10.4232/1.10188.

Feagin, J. R. (1972). We still believe that God helps those who help themselves. Psychology Today, 6, $101-129$.

Feather, N. (1974). Explanations of poverty in Australian and American samples: The person, society, or fate? Australian Journal of Psychology, 26(3), 199-216. doi:10.1080/00049537408255231.

Fenger, H. (2007). Welfare regimes in Central and Eastern Europe: Incorporating post-communist countries in a welfare regime typology. Contemporary Issues and Ideas in Social Sciences, 3(2), 3-30. http://journal.ciiss.net/index.php/ciiss/article/viewArticle/45.

Ferge, Z. (1997). The changed welfare paradigm: The individualization of the social. Social Policy \& Administration, 31(1), 20-44. doi:10.1111/1467-9515.00035.

Fodor, E., Wnuk-Lipinski, E., \& Yershova, N. (1995). The new political and cultural elite. Theory and Society, 24(5), 783-800.

Ganzeboom, H. B. G., De Graaf, P. M., \& Treiman, D. J. (1992). A standard international socioeconomic index of occupational status. Social Science Research, 21(1), 1-56. doi:10.1016/0049089x(92)90017-b.

Ganzeboom, H. B. G., \& Treiman, D. J. (1996). Internationally comparable measures of occupational status for the 1988 International Standard Classification of Occupations. Social Science Research, 25, 201-239.

GESIS. (2011). EVS 2008-Variable report integrated dataset. Köln. doi:10.4232/1.11004.

Gijsberts, M. (2002). The legitimation of income inequality in state-socialist and market societies. Acta Sociologica, 45(4), 269-285. doi:10.1080/000169902762022860. 
Giuliano, P., \& Spilimbergo, A. (2013). Growing up in a recession. Review of Economic Studies, 81(2), 787-817. doi:10.1093/restud/rdt040.

Gugushvili, A. (2010). Towards a welfare research framework in the countries of Eastern Partnership Initiative. Journal of East European and Asian Studies, 1(3), 351-381.

Gugushvili, A. (2014). Trends, covariates and consequences of intergenerational social mobility in postsocialist societies (Thesis). Political and social sciences. Florence: European University Institute.

Gugushvili, A. (2015a). Economic liberalization and intergenerational mobility in occupational status. Comparative Sociology, 14(6), 790-820. doi:10.1163/15691330-12341368.

Gugushvili, A. (2015b). Self-interest, perceptions of transition and welfare preferences in the New Eastern Europe and the South Caucasus. Europe-Asia Studies, 67(5), 718-746. doi:10.1080/ 09668136.2015.1045451.

Gugushvili, A. (2016). Intergenerational objective and subjective mobility and attitudes towards income differences: Evidence from transition societies. Journal of International and Comparative Social Policy, 32(3), 199-219. doi:10.1080/21699763.2016.1206482.

Habibov, N. (2011). Public beliefs regarding the causes of poverty during transition: Evidence from the Caucasus, Central Asia, Russia, and Ukraine. International Journal of Sociology and Social Policy, 31(1/2), 53-74. doi:10.1108/01443331111104805.

Heath, A. F., Jowell, R., \& Curtice, J. (1985). How Britain votes (1st ed.). Oxford, Oxfordshire: Pergamon Press.

Hout, M., \& DiPrete, T. A. (2006). What we have learned: RC28's contributions to knowledge about social stratification. Research in Social Stratification and Mobility, 24(1), 1-20. doi:10.1016/j.rssm. 2005.10.001.

ILO. (2010). ISCO - 88, International Standard Classification of Occupation (Report). Genève: International Labour Organisation.

Inglehart, R. (1997). Modernization and postmodernization: Cultural, economic, and political change in 43 societies. Princeton, NJ: Princton University Press.

Jaime-Castillo, A. M., \& Mareques-Perales, I. (2014). Beliefs about social fluidity and preferences for social policies. Journal of Social Policy, 43(3), 615-633. doi:10.1017/S0047279414000221.

Jennings, M. K., \& Markus, G. B. (1984). Partisan orientations over the Long Haul: Results from the three-wave political socialization panel study. The American Political Science Review, 78(4), 1000-1018. doi:10.2307/1955804.

Jerrim, J., \& Macmillan, L. (2015). Income inequality, intergenerational mobility, and the great gatsby curve: Is education the key? Social Forces, 94(2), 505-533. doi:10.1093/sf/sov075.

Kallio, J., \& Niemelä, M. (2014). Who blames the poor? Multilevel evidence of support for and determinants of individualistic explanation of poverty in Europe. European Societies, 16(1), 112-135. doi:10.1080/14616696.2013.787435.

Karaca-Mandic, P., Norton, E. C., \& Dowd, B. (2012). Interaction terms in nonlinear models. Health Services Research, 47(1), 255-274. doi:10.1111/j.1475-6773.2011.01314.x.

Kelley, S. M. C., \& Kelley, C. G. E. (2009). Subjective social mobility: Data from 30 nations. In M. Haller, R. Jowell, \& T. Smith (Eds.), Charting the globe: The International Social Survey Programme (pp. 1984-2009). London: Routledge.

Kluegel, J. R., Mason, D. S., \& Wegener, B. (1995). Social justice and political change: Public opinion in capitalist and post-communist States. New York: Gruyter.

Kluegel, J. R., \& Smith, E. R. (1986). Beliefs about inequality: Americans' views of what is and what ought to be. New York: Aldine Transaction.

Kreidl, M. (2000). Perceptions of poverty and wealth in western and post-communist countries. Social Justice Research, 13(2), 151-176. doi:10.1023/a:1007597807110.

Lepianka, D., Gelissen, J., \& van Oorschot, W. (2010). Popular explanations of poverty in Europe: Effects of contextual and individual characteristics across 28 European countries. Acta Sociologica, 53(1), 53-72. doi:10.1177/0001699309357842.

Lepianka, D., Van Oorschot, W., \& Gelissen, J. (2009). Popular explanations of poverty: A critical discussion of empirical research. Journal of Social Policy, 38(3), 421-438. doi:10.1017/ S0047279409003092.

Lewin-Epstein, N., Kaplan, A., \& Levanon, A. (2003). Distributive justice and attitudes toward the welfare state. Social Justice Research, 16(1), 1-27. doi:10.1023/A:1022909726114.

Linos, K., \& West, M. (2003). Self-interest, social beliefs, and attitudes to redistribution. Re-addressing the issue of cross-national variation. European Sociological Review, 19(4), 393-409. doi:10.1093/ esr/19.4.393. 
Lipset, S. M. (1992). Foreword: The political consequences of social mobility. In F. C. Turner (Ed.), Social mobility and political attitudes: Comparative perspectives (pp. XV-XXIII). New Brunswick, NJ: Transaction Publishers.

Marshall, G., \& Firth, D. (1999). Social mobility and personal satisfaction: Evidence from ten countries. The British Journal of Sociology, 50(1), 28-48. doi:10.1111/j.1468-4446.1999.00028.x.

Marshall, G., \& Swift, A. (1996). Merit and mobility: A reply to Peter Saunders. Sociology, 30(2), 375-386. doi:10.1177/0038038596030002011.

Marshall, G., Swift, A., \& Roberts, S. (1997). Against the odds? Social class and social justice in industrial societies. New York; Oxford: Clarendon Press; Oxford University Press.

Meltzer, A. H., \& Richard, S. F. (1981). A rational theory of the size of government. Journal of Political Economy, 89(5), 914-927. http://www.jstor.org/stable/1830813.

Mezulis, A. H., Abramson, L. Y., Hyde, J. S., \& Hankin, B. L. (2004). Is there a universal positivity bias in attributions? A meta-analytic review of individual, developmental, and cultural differences in the self-serving attributional bias. Psychological Bulletin, 130(5), 711-747. doi:10.1037/0033-2909. 130.5.711.

Milanovic, B. (1999). Explaining the increase in inequality during transition. Economics of Transition, 7(2), 299-341. doi:10.1111/1468-0351.00016.

Miller, D. T., \& Ross, M. (1975). Self-serving biases in the attribution of causality: Fact or fiction? Psychological Bulletin, 82(2), 213-225. doi:10.1037/h0076486.

Morçöl, G. (1997). Lay explanations for poverty in Turkey and their determinants. The Journal of Social Psychology, 137(6), 728-738. doi:10.1080/00224549709595494.

Murthi, M., \& Tiongson, E. R. (2009). Attitudes to income equality: The "Socialist Legacy" revisited. Comparative Economic Studies, 51(3), 344-366. doi:10.1057/ces.2009.4.

Niemela, M. (2008). Perceptions of the causes of poverty in Finland. Acta Sociologica, 51(1), $23-40$. doi:10.1177/0001699307086816.

Oorschot, W. Van, \& Halman, L. (2000). Blame or fate, individual or social? European Societies, 2(1), 1-28. doi:10.1080/146166900360701.

Parkin, F. (1973). Class inequality and political order: Social stratification in capitalist and communist societies. London: Paladin.

Parsons, T., \& Shils, E. (Eds.). (1951). Toward a general theory of action. Cambridge: Harvard University Press.

Piketty, T. (1995). Social mobility and redistributive politics. The Quarterly Journal of Economics, 110(3), 551-584. doi:10.2307/2946692.

Pop-Eleches, G., \& Tucker, J. A. (2014). Communist socialization and post-communist economic and political attitudes. Electoral Studies, 33, 77-89. doi:10.1016/j.electstud.2013.06.008.

Rona-Tas, A., \& Guseva, A. (2001). The privileges of past communist party membership in Russia and endogenous switching regression. Social Science Research, 30(4), 641-652. doi:10.1006/ssre.2001. 0711.

Ross, L. (1977). The intuitive psychologist and his shortcomings: Distortions in the attribution process. Advances in Experimental Social Psychology, 10(C), 173-220. doi:10.1016/S0065-2601(08)60357-3.

Ryder, N. B. (1965). The cohort as a concept in the study of social change. American Sociological Review, 30(6), 843-861. doi:10.2307/2090964.

Schmidt, A. (2011). The experience of social mobility and the formation of attitudes toward redistribution. GK SOCLIFE Working Papers Series, WP 6/2011. Cologne: Cologne Graduate School in Management, Economics and Social Sciences, University of Cologne.

Segura, D. A. (1989). Chicana and mexican immigrant women at work: The impact of class, race, and gender on occupational mobility. Gender and Society, 3(1), 37-52. doi:10.1177/089124389003001003.

Semin, G. R., \& Zwier, S. M. (1997). Social cognition. In J. W. Berry, M. H. Segall, \& C. Kagitçibasi (Eds.), Handbook of cross-cultural psychology: Social behavior and applications (Vol. 3, pp. 51-75). Boston: Allyn and Bacon.

Shariff, A., Wiwad, D., \& Aknin, L. (2016). Income mobility breeds tolerance for income inequality: Cross-national and experimental evidence. Perspectives on Psychological Science, 11(3), 373-380. doi:10.1177/1745691616635596.

Shepelak, N. J., \& Alwin, D. F. (1986). Beliefs about inequality and perceptions of distributive justice. American Sociological Review, 51(1), 30. doi:10.2307/2095476.

Shirazi, R., \& Biel, A. (2005). Internal-external causal attributions and perceived government responsibility for need provision: A 14-culture study. Journal of Cross-Cultural Psychology, 36(1), 96-116. doi:10.1177/0022022104271428. 
Smith, A. (1817). An inquiry into the nature and causes of the wealth of nations (2nd ed.). Edinburgh: Oliphant, Waugh \& Innes.

Smith, M. L. (2010). Perceived corruption, distributive justice, and the legitimacy of the system of social stratification in the Czech Republic. Communist and Post-Communist Studies, 43(4), 439-451. doi:10.1016/j.postcomstud.2010.10.005.

Smith, M. L., \& Matějů, P. (2012). Two decades of value change: The crystallization of meritocratic and egalitarian beliefs in the Czech Republic. Social Justice Research, 25(4), 421-439. doi:10.1007/ s11211-012-0164-9.

Smith, K. B., \& Stone, L. H. (1989). Rags, riches, and bootstraps: Beliefs about the causes of wealth and poverty. The Sociological Quarterly, 30(1), 93-107. doi:10.1111/j.1533-8525.1989.tb01513.x.

Solt, F. (2009). The Standardized World Income Inequality Database-http://hdl.handle.net/1902.1/ 11992 V4 [Version] (Report). Cambridge, MA: Harvard University.

Stephenson, S. (2000). Public beliefs in the causes of wealth and poverty and legitimization of inequalities in Russia and Estonia. Social Justice Research, 13(2), 83-100. doi:10.1023/A: 1007541722131.

Swift, A. (2000). Class analysis from a normative perspective. British Journal of Sociology, 51(4), 663-679. doi:10.1080/00071310020015316.

Swift, A. (2004). Would perfect mobility be perfect? European Sociological Review, 20(1), 1-11. doi:10. 1093/esr/20.1.1.

Szelényi, I., \& Szelényi, S. (1995). Circulation or reproduction pf elites during the postcommunist transformation of Eastern Europe. Theory and Society, 24(5), 615-638. doi:10.1007/bf00993400.

Tabellini, G. (2010). Culture and institutions: Economic development in the regions of Europe. Journal of the European Economic Association, 8(4), 677-716. doi:10.1111/j.1542-4774.2010.tb00537.x.

Titmuss, R. M. (1970). The gift relationship: From human blood to social policy. London: Allen \& Unwin.

Tooth, L., \& Mishra, G. (2013). Intergenerational educational mobility on general mental health and depressive symptoms in young women. Quality of Life Research, 22(7), 1589-1602. doi:10.1007/ s11136-012-0310-8.

van den Berg, M. (2011). Subjective social mobility: Definitions and expectations of "moving up" of poor Moroccan women in the Netherlands. International Sociology, 26, 503-523. doi:10.1177/ 0268580910393042.

Veraschagina, A. (2012). Chapter 4: Education and socioeconomic mobility in post-communist countries. In G. Parodi \& D. Sciulli (Eds.), Social exclusion: Short and long term causes and consequences (p. 67). Heidelberg: Physic a -Verlag - A Springer Company.

Weber, M. (1978). Economy and society. London: University of California Press.

Weber, M. (2005). The protestant ethic and the spirit of capitalism. London: Routledge.

Wegener, B. (2000). Political culture and post-communist transition-A social justice approach: Introduction. Social Justice Research, 13(2), 75-82. doi:10.1023/A:1007512305293.

Wegener, B., \& Liebig, S. (1995). Hierarchical and Social Closure Conceptions of Distributive Social Justice: A Comparison of East and West Germany. In J. R. Kluegel, D. S. Mason, \& B. Wegener (Eds.), Social justice and political change: Public opinion in capitalist and post-communist states. Berlin, New York: De Gruyter. doi:10.1515/9783110868944.263.

Wolf, M. M. (1978). Social validity: The case for subjective measurement or how applied behavior analysis isfinding its heart. Journal of Applied Behavior Analysis, 11(2), 203-214. doi:10.1901/jaba. 1978.11-203.

World Bank. (2015). World development indicators 2015 (Report). Washington, D.C.: World Bank.

Zucker, G. S., \& Weiner, B. (1993). Conservatism and perceptions of poverty: An attributional analysis. Journal of Applied Social Psychology, 23, 925-943. doi:10.1111/j.1559-1816.1993.tb01014.x. 